J O U R N A O F French and Francophone Philosophy
RE V UE DE LA

philosophie française et de langue française

\title{
'So Much the Worse for the Whites': Dialectics of the Haitian Revolution
}

George Ciccariello-Maher

Journal of French and Francophone Philosophy - Revue de la philosophie française et de langue française, Vol XXII, No 1 (2014) pp. 19-39.

\author{
Vol XXII, No 1 (2014) \\ ISSN 1936-6280 (print) \\ ISSN 2155-1162 (online) \\ DOI $10.5195 /$ jffp. 2014.641 \\ www.jffp.org
}

\section{(c)) EY-NC-ND}

This work is licensed under a Creative Commons Attribution-Noncommercial-No Derivative Works 3.0 United States License.

\section{ULIS D-Sunt}

This journal is operated by the University Library System of the University of Pittsburgh as part of its D-Scribe Digital Publishing Program, and is co-sponsored by the University of Pittsburgh Press 


\title{
'So Much the Worse for the Whites':
}

Dialectics of the Haitian Revolution

\author{
George Ciccariello-Maher \\ Drexel University
}

\begin{abstract}
Civilization-mongers who throw hot shells on a defenseless city and add rape to murder, may call the system cowardly, barbarous, atrocious; but what matters it to the Chinese if it be only successful? Since the British treat them as barbarians, they cannot deny to them the full benefit of their barbarism.
\end{abstract}

-Friedrich Engels, New York Daily Tribune (May 20, 1857)

We are witnessing a rebirth of dialectical thought. Whether in recent attempts to rethink the Hegelian legacy, to renovate the Marxist and communist tradition, or to mobilize against the current political and economic crises racking the globe, the question of dialectics - what it means, how it operates - is once again on the table. ${ }^{1}$ In this process, the dialectical questions par excellence-what to preserve and what to discard, how to move forward without reproducing the errors of the past-are reposed with heightened urgency. This renewal of interest in dialectical thinking has coincided with a veritable explosion of literature on the Haitian Revolution, a not unrelated phenomenon. After all, what was the Haitian Revolution if not a dialectical outburst in the last place master dialecticians would ever have looked? And what is its historical erasure, which Sibylle Fischer deems a "disavowal," if not both a anxious recognition of the radical potential of the world's first successful anti-colonial revolution and a silent admonishment of the impudence of the slaves for having decided to act not merely as humans, but as standard-bearers of historical progress. ${ }^{2}$

This intersection of Haiti and dialectical thought speaks to the fraught relationship between dialectics and decolonization, one long characterized by mutual suspicion. On the one hand, while Hegel and especially Marx 
have long served as go-to sources for struggles emerging from the global periphery, these same authors have been viewed with skepticism due to their shared Eurocentrism and the linear, progressive, determinist, and teleological nature of their approaches. As a result, most postcolonial theory, especially in its more heavily post-structuralist variants, has "eluded engagement with... the reworking of dialectical thinking." ${ }^{3}$ Viewed from the opposite direction, however, this postcolonial suspicion is not without reason, as contemporary neo-dialecticians have done little to alleviate the concerns of their would-be decolonial allies. ${ }^{4}$ Reacting to post-structuralist and postcolonial critiques of the universal, thinkers from Slavoj Žižek to Alain Badiou have effectively bent the stick in the opposite direction, occasionally to a troubling degree: Badiou is openly hostile to a politics of difference and has been quick to embrace the universal, while Žižek - with a characteristic zeal for the provocative-has gone even further in urging the left to openly embrace Eurocentrism. ${ }^{5}$ But as a boomerang effect of the poststructural politics of difference, much is missed in this precipitous return swing toward the universal. In what follows, I turn to the Haitian Revolution as a lens for sketching out the conditions of possibility for a decolonized dialectics, with the following questions in mind. Firstly, against those who discard dialectics out of hand, is it possible to subject the dialectical tradition to its own decolonizing Aufhebung? Secondly, and inversely, is there a dialectic capable of accommodating the Haitian Revolution, or is the historical baggage of dialectical thought too heavy to be worth the trouble?

One possible answer to such challenges lies precisely at the intersection of Haiti and dialectical thought: Susan Buck-Morss' groundbreaking essay "Hegel and Haiti" and more recent expansion on the theme in Hegel, Haiti, and Universal History. ${ }^{6}$ Having herself contributed to the task of keeping the dialectical flame alive, Buck-Morss' positioning toward these disparate trends nevertheless seems unclear. ${ }^{7}$ Does she, by drawing Hegel and Haiti together, lay the basis for a thorough decolonization of the former? Or does her invocation of universal history point instead in a very different direction? If Žižek's own celebration of "Hegel and Haiti" as "the most succinct formula of communism" is any indication, we might have some grounds for concern. But is Žižek correct to hail Buck-Morss' text as an antidote to "the postmodern poetry of diversity," and does her analysis truly cast the universal as "underlying sameness," as Žižek argues? ${ }^{8}$ To approach these questions, I track Buck-Morss' resuscitation of the universal, drawing it into conversation, firstly, with C.L.R. James' account of the Haitian Revolution, and secondly, with Frantz Fanon's overlooked reformulation of the Hegelian dialectic of lordship and bondage, which I consider more generative for the task of decolonizing dialectical thought. 


\section{Resuscitating the Universal}

Hegel, Haiti, and Universal History is a beautiful if peculiar book, and if its beauty is evident from the front cover, its peculiarity is announced on the back. There, Walter Mignolo credits Buck-Morss with revealing that "Hegel's spirit is tainted with the blood and suffering of enslaved Africans," while Timothy Brennan praises Buck-Morss' revelation that "the young Hegel wrote The Phenomenology in a passionate defense of freedom." Were these two even reading the same book, or does this schizophrenia that marks the book's reception reveal something deeper about the text itself? The beginning of an answer lies on the very first page, in Buck-Morss' own admission of the uncomfortable in-betweenness of her intervention: "It pleased the academic critics of Eurocentrism [e.g. Mignolo], but not entirely," and this due to the "less popular goal of salvaging modernity's universal intent" (ix).

In her original article on "Hegel and Haiti," Buck-Morss had sought to bridge the gulf of silence separating Hegel's Phenomenology of Spirit from the concurrent revolutionary upsurge in Haiti, demonstrating convincingly that, in short, "Hegel knew" (59). Beyond merely knowing, moreover, BuckMorss argued-here venturing onto less solid but more fascinating ground - that the Haitian Revolution functioned as the unspoken inspiration for Hegel's early dialectic of lordship and bondage. This young Hegel was a radical, according to Buck-Morss, who retreated only later into a thinly veiled Eurocentrism according to which most non-Europeans were barbaric and slavery - which he had previously considered an unmitigated affront to human freedom - would disappear more gradually than suddenly (68). This distinction between two Hegels is not uncommon today, but for Buck-Morss the implications are very specific: she reclaims Hegel because she is committed to "rescuing the idea of universal human history" from both white supremacist reality and Hegel's own late conservatism (74).

When Buck-Morss turns more directly to this task, the urgency is provided by the need to confront neoliberalism on its own global terrain. We simply must learn to think globally, but doing so is not without its potent dangers, to which Hegel had succumbed too easily: "Concept took precedence over content" and the particular was zealously subsumed to the universal as system (115). If we are to rethink universal history, this balance between universal and particular must be restored. There is neither an "anticipation of unity" nor a neglect of difference in this task, Buck-Morss insists - here at least nominally rejecting Žižek's insistence on sameness but rather the effort to skirt the fine line between the two, thinking in potentially universal terms while not caving to a priori assumptions of incommensurability. Her goal is to grasp the universal "not by subsuming facts within overarching systems or homogenizing premises, but by attending to the edges... the boundaries of our historical imagination in order to trespass, trouble, and tear these boundaries down" (79). Against 
Hegel's "systematized comprehension," then, Buck-Morss recasts universal history in terms of the "conceptual ordering" of the particular in a way that "sheds light on the political present" (x). Those "undisciplined" moments when individuals unexpectedly break out of pre-existing structures of understanding and political action must be our "absolute spirit" (75).

Practically, this means setting out from a skepticism toward prevailing political categories and especially identities, which are so laden with "residues of the past" that they cloud our political vision while contributing to a "recurring cycle of victim and aggressor" (150). To transcend such exclusive identities (of race, nation, and class) and begin to imagine "collective subjectivity... as inclusive as humanity itself," Buck-Morss emphasizes the "porosity" of these identities and the contingency of the exclusion they mark (110-111). But the question for our task is whether Buck-Morss' approach to the universal successfully escapes the "anticipation of unity" that she rejects as having so overdetermined Hegel's approach, or if in her zealous rejection of identities she has fallen into precisely the same anti-dialectical pitfall. This question, furthermore, turns on the question of how her own "conceptual ordering" is carried out: According to what "overarching framework," does Buck-Morss' own rejection of exclusionary political identities operate? Has no residual dust of the past clouded her own view or settled upon her own understanding of porosity?

\section{Universalizing Toussaint}

There is no better entry-point into these questions than Buck-Morss' concrete analysis of the Haitian Revolution, whose temporal progression she distills in the following terms:

For almost a decade, before the violent elimination of whites signalled their deliberate retreat from universalist principles, the black Jacobins of Saint-Domingue surpassed the metropole in actively realizing the Enlightenment goal of human liberty, seeming to give proof that the French Revolution was not simply a European phenomenon but world-historical in its implications (39).

Here, there is much to unpack. Firstly, Buck-Morss argues that during a brief period, the Haitian Revolution "surpassed the metropole," but the parameters of this surpassing are revealing. Toussaint's Constitution "took universal history to the farthest point of progress," thereby "compelling the French Jacobins (at least temporarily) to follow their lead" (94). However, Buck-Morss immediately reinscribes the importance of this surpassing, reading the Haitian experience through the lenses of both the French Revolution and, more surprisingly still, the European Enlightenment as a whole. ${ }^{9}$ Hence the colony surpasses the metropole but only according to the criteria of the latter, and thus it is the French Revolution that is "world- 
historical in its implications," with its Haitian counterpart serving as "the crucible, the trial by fire for the ideals of the French Enlightenment" (39, 42). ${ }^{10}$ And not just any ideals: as Buck-Morss' own "conceptual ordering" surfaces, delimiting what part of the Haitian Revolution effectively counts, it becomes clear that it is neither fraternité nor égalité but rather liberté that stands as the ultimate yardstick for the universal. What sort of surpassing is this?

This privileging of the Enlightenment notion of liberty not only betrays a troubling Eurocentrism, but also sets the stage for Buck-Morss' historical delimitation of the Haitian Revolution's universal credentials, generating a series of silences in the process, which are doubly-ironic given Buck-Morss' method in which breaking silences figures prominently. In an effort to reconsider the Haitian Revolution in a manner faithful to this aspiration, I will turn to C.L.R. James' account in The Black Jacobins, which offers a partial prelude to the more ambitious critique of Buck-Morss' universal that I find in Frantz Fanon. The first of these silences emerges in Buck-Morss' delimitation of the "almost a decade" of the Haitian Revolution that counts. This "universal" period is coterminous with Toussaint L'Ouverture's leadership, and centers upon his 1801 Constitution, which "took universal history to the farthest point of progress by extending the principle of Liberty to all residents regardless of race" (94). These former slaves had "forever abolished" servitude and had even, by defining this abolition in terms of territory rather than race or citizenship, drawn closer to the universal than even their French counterparts. Yet Buck-Morss seems strangely unconcerned with the precise wording of this ostensibly universal statement - which declares all Haitian men "free and French" - and in which the very notion of freedom is bound as if by synonymy to the mother country. ${ }^{11}$ How universal could colonial rule possibly be, especially given the constant threat of re-enslavement?

Not only is European liberty the metric of progress, but Buck-Morss has further driven a wedge between emancipation and independence, thereby lowering the bar of the universal considerably. While this is worrying, what is arguably more peculiar about upholding Toussaint as emblematic of universal history is that, on a very concrete level, Toussaint was a failure. He did not defeat the French (which he never truly intended to do), could not guarantee the perpetual abolition of slavery (which he certainly intended to do), was captured in 1802, and died a prisoner at Fort de Joux in 1803 while his compatriots continued to struggle. The deeper causes behind this failure-which are not unrelated to Toussaint's character or politics - as well as the powerful lessons it offers, do not appear in Buck-Morss' account. Moreover, once we reincorporate these into the discussion by reading Hegel, Haiti, and Universal History through The Black Jacobins, we find considerable reason to doubt Buck-Morss' suggestion that Toussaint marked the furthest 
progress of the universal and that the events following his capture represented a "retreat" from the universal at all.

Quite despite his own initial objectives, C.L.R. James has drawn out Toussaint's errors more fully than any other account, errors which led to Toussaint's failure and death and yet which Buck-Morss transforms into virtues. On the most concrete level, Toussaint's primary error lay in his effort to "conciliate whites at home and abroad" by granting not only equality but even privileges, symbolic and material, to the local whites (262). "The black labourers," according to James, "did not approve of Toussaint's policy. They felt that he showed too much favour to their old enemies," but "old" was a rather generous adjective to attach to the term "enemies" in this case (261). This was neither jealous resentment nor a mystical intuition, but rather the sort of sharpened awareness that results from a history of oppression alongside quotidian threats - both subtle and obvious - that they would be slaves once again. "The blacks could see in the eyes of their former owners the regret for the old days and the hatred," and as a result, the biological content of the category "white" was displaced by its political content: "the whites were whites of the old régime," and the ostensibly "anti-white feelings" of the Blacks "meant only anti-slavery" $(261,286,174)$.

That Toussaint was unable to see this is a testament to the blinding brilliance of the universal. Moderate in character and education, enamored of the Rights of Man and principles of abstract equality, he saw only the forest of the future at the expense of the trees of the present and consequently "set his face sternly against racial discrimination" (261). But in so doing, Toussaint lost sight of his own mass base, and that base gradually grew disillusioned. With such disillusionment comes the perennial temptation of investing one's hopes elsewhere, and Toussaint's own nephew Moïse, the unofficial leader of a mass rebellion against his uncle's previously undisputed leadership, served as this alternative vessel. The rebellion was put down with deaths in the thousands, and Moïse was summarily executed. While the nature of Moïse's rebellion is debated, and while James is quick to insist that he "was not anti-white" either, it is clear that the rebellion sought Black unity and slaughter of the whites as at least a partial means toward "complete emancipation" (276).

That they should get their property back was bad enough. That they should be privileged was intolerable. And to shoot Moïse, the black, for the sake of the whites was more than an error, it was a crime. It was almost as if Lenin had had Trotsky shot for taking the side of the proletariat against the bourgeoisie (284).

In "a community where whites stood for so much evil," this was an error of epic proportions.

By executing Moïse, “Toussaint, like Robespierre, destroyed his own Left-wing, and with it sealed his own doom," but this was not Toussaint's 
only error, nor even his fundamental one. Were this the case, the lesson from Toussaint and Robespierre alike would be the same: radical leaders must watch their left, pay attention to the need and demands of their base. But for James:

The tragedy was that there was no need for it. Robespierre struck at the masses because he was bourgeois and they were communist. That clash was inevitable, and regrets over it are vain. But between Toussaint and his people there was no fundamental difference of outlook or of aim (286).

What initially appeared under a single concept (losing the masses) here divides into two according to its content: losing the masses inevitably (Robespierre) versus losing the masses tragically (Toussaint). The two cases share little more than formal characteristics, and by introducing this scission into the concept James alerts us to a very different lesson, one that touches the very heart of the universal. Since there was "no fundamental difference" between Toussaint and his masses-all were subject to the threat of perpetual enslaveability - the explanation lay elsewhere: in his uncritical embrace of the universal as immediately accessible. It was this that led Toussaint to oppose not only discrimination, but any form of racial identity that interfered with the establishment of formal equality in the here and now. It was this that led to Toussaint's favoring of the whites, his concomitant distancing from the Black masses, and finally to his execution of Moïse as the very embodiment of a one-sided nationalist dialectic. Moreover, it is this error that lay at the heart of Buck-Morss' celebration of Toussaint's universal status.

In marking the "violent elimination of whites" as the end of Haiti's pursuit of the universal, Buck-Morss transforms Toussaint's errors into virtues while gesturing toward the latent criteria for her own universal. As though responding preemptively to her celebration of Toussaint's universality, James insists that: "These anti-white feelings of the blacks were no infringement of liberty and equality, but were in reality the soundest revolutionary policy" (261). These uneducated former slaves intuitively grasped what escaped their enlightened leader: that the white colonists wanted slavery back, and that Napoleon was attempting to make that wish a reality. If anything stood as a barrier to universal emancipation-not to mention equality - it was tolerance for these same whites, and "if to make matters clear to them Toussaint had to condone a massacre of the whites, so much the worse for the whites" (286). This was not a question of bending principles to fit strategy (and much less tactics), but rather a question of the role of (universal) political principles more generally.

But ironically, Buck-Morss' breaking of the silence surrounding Hegel and Haiti also bespeaks a serious silencing in its own right: that of Toussaint's successor Jean-Jacques Dessalines and the dialectics of black and 
national identity that he (like Moïse) represented. As Henri Christophe would later put it, Toussaint's arrest "was the recompence for his attachment to France," but this was not merely a question of fidelity to the mother country. Toussaint had neglected something more fundamental: he had forgotten that "that negro wail was not without reason."12 But if Toussaint failed to grasp the subjective orientation of the black masses, for whom hatred toward the colonizer remained a primary and generative emotion, Dessalines would not make the same mistake.

\section{Silencing Dessalines}

Toussaint and Dessalines constitute two poles of what David Scott has termed the "paradox of Enlightenment."13 Where Dessalines still bore "the marks of the whip on his skin," Toussaint was "unwarped" by slavery (James, 373, 92); Toussaint was educated, Dessalines was not; Toussaint sought conciliation, Dessalines was vengeful; and by no coincidence, Toussaint hesitated, while Dessalines "hurled himself." As James put described it in his later "Lectures on the Black Jacobins":

Toussaint had not hurled himself against the French. If he had done so from the start he might have got through, but the man who hurled himself was Dessalines. Toussaint didn't hurl himself because he was a highly civilized creature, and Dessalines hurled himself because he was a "barbarian." Dessalines did not have the restraints that Toussaint had, but it was those restraints and that knowledge that helped Toussaint to build the state and the army which Dessalines was able to use. ${ }^{14}$

This is not a question, for James, of the superiority of one over the other, but of a precise dialectical relation in which Toussaint's organizational capacities (rather than his universal ethic) serve as the necessary precondition for Dessalines' victory. But the conceptually distinguishable is not always practically separable, and while Toussaint's organizational capacities would not doom him, his universalism would: "Dessalines...saw what was under his nose so well because he saw no further. Toussaint's failure was the failure of enlightenment, not of darkness" (288). Dessalines was successful precisely because he could see only so far as the middle of the dialectic, and because he wasted little energy squinting to make out universal forms on the distant horizon. ${ }^{15}$

Unlike Toussaint, Dessalines - like Henri Christophe - recognized that the "wail" of the colonized contained its own "reason," and that this reason serves as an obligatory point of departure in the struggle. Dessalines had "found the correct method," a method borne out in practice, in the subjective response of the masses to a new policy of opposition to the French and their local proxies: "Loud acclamations greeted this bold pronouncement, worth a 
thousand of Toussaint's equivocal proclamations reassuring the whites. Dessalines had not the slightest desire to reassure whites." The whitesunderstood politically rather than phenotypically - were irrelevant except as enemies, and "Dessalines did not care what they said or thought. The black laborers had to do the fighting-and it was they who needed reassurance" (287). Dessalines had properly grasped the objective importance of the subjective element of the struggle, the need to begin not from abstractly universal principles, but instead from that concrete action that is the only path toward equality.

Despite the fact that Dessalines remedied the error of Toussaint's immediate universalism, his presence in Hegel, Haiti, and Universal History is spectral at best: mentioned on only a few occasions, but looming in the background nevertheless as the antithesis of the universal. Toward the end of her original essay, however, Buck-Morss surprisingly concedes that "even Dessalines" matters, since "for all his brutality and revenge against whites, Dessalines saw the realities of European racism most clearly" (75). Not only did Dessalines excel in grasping these realities, according to Buck-Morss but also in acting upon them: it was he who "took the final step" by declaring independence, with "complete freedom" as the result (38). But surely this is the point! If Dessalines succeeded and freedom was the result, then it would seem as though-even by Buck-Morss' delimited definition of the universal - he would be the central actor in this drama. And yet, Dessalines' embrace of the simmering anti-white sentiment of the Black masses constituted a break with universal history, a retreat. To speak in universals but fail in practice, or to expand freedom in practice without using the words - which is more universal?

For Buck-Morss, this peculiarity is resolved in the slaughter of the whites and the identitarian politics such an action embodied. But while insisting that the massacre of the whites was a "tragedy," in manner that might appear compatible with Buck-Morss, James immediately clarifies that this was not a tragedy "for the whites."

For these old slave-owners, those who burnt a little powder in the arse of a Negro, who buried him alive for insects to eat, who were well treated by Toussaint, and who, as soon as they got the chance, began their old cruelties again; for these there is no need to waste one tear or one drop of ink. The tragedy was for the blacks and the Mulattoes (373).

In so doing, he distances even his own ambivalent praise of Toussaint and critique of Dessalines from Buck-Morss' own approach, but he also goes a step further. Whereas Buck-Morss, however inadvertently, centers the biologically-white colonists in her determination of what period of the Haitian Revolution matters, James instead explicitly decenters the 
politically-white colonists as a measure of progress and instead insists that they stood as little more than a barrier to the universal.

The true measure - for James as for Dessalines - was the demands of the Black masses, and here James introduces a distinction that troubles BuckMorss' account. In a footnote added to the 1963 edition of The Black Jacobins whose importance he would later emphasize in his "Lectures," James distinguishes the Jacobins from the sansculottes, sumperimposing this distinction onto Toussaint and supporters of Moïse. Whereas the Jacobins were authoritarian "enlightened despots," the sansculottes "wanted to exercise their own dictatorship against the aristocracy, but among themselves they wanted to have a free democratic state." ${ }^{16}$ Similarly, those who rose up against Toussaint wanted "to keep [the whites] in subjection" while exercising democracy among themselves. ${ }^{17}$ Popular democracy, in this view, is not incompatible with the repression of an avowed enemy, and to do so does not detract from the establishment of universal equality in the future.

This distinction between Jacobins and sansculottes is troublingly absent from Buck-Morss' account. Not only do dead whites mark the retreat from the universal in her account, but she also neglects other, more troubling attacks on the internal heterogeneity of the Haitian revolutionaries themselves. Why was it "the violent elimination of the whites" and not the prior elimination of various maroon and Vodou and other leaders that "signalled" a retreat from the universal? ${ }^{18}$ This internal homogenization always a temptation (but never a necessary outcome) in a moment of severe opposition-should worry us far more than the direct elimination of the external enemy. For the latter, James had rightly refused "to waste one tear or one drop of ink." By contrast, Buck-Morss reduces all identitarian opposition to brutality, which can only contribute to an interminable cycle of violence and the "eye-for-an-eye, tooth-for-a-tooth logic of political Jihad" (143). As a result, she misreads the dialectical content of both Dessalines' Manichaeism (in the 1804 Declaration of Independence) and the universal blackness of all Haitians (as formulated in the 1805 Constitution).

The 1804 Declaration constitutes a riposte to Toussaint's errors and the abstract universalism of the 1801 Constitution. ${ }^{19}$ The document openly critiques the formalism of the Rights of Man, going a step further to argue that not only were words like "liberty," "equality," and "fraternity" insufficient, but such abstract principles had proven positively dangerous: the Haitian rebels were "defeated not by French armies, but by the pathetic eloquence of their agents' proclamations." 20 But while this is certainly a Manichean text, one that derides the French as a "barbarous people" and insists that "they are not our brothers...they never will be," this is not the caricatured brutality of Buck-Morss' "political Jihad." The insistence that French and Haitians will never be brothers, for example, is immediately qualified by the suspicion that they will never behave as such. Even the most 
brutal passages seek to offer "terrible, but just" proof that those who have gained liberty will not easily relinquish it, proudly invoking vengeance but situating it within a dialectic of liberation. While universal human reconciliation is certainly deferred, it is not infinitely so, since anti-French sentiment is but a necessary first step allowing the Haitian people to "be thus by ourselves and for ourselves" (arguably prefiguring Hegel's An-undfür-sich-sein). This is not a document that seeks to halt universal progress, but one that is instead grasping toward that universal on the visceral knowledge that the French presence has been only a fetter to it.

If the Manichaeism of the 1804 Declaration was more dialectical than Buck-Morss would liketo admit, the same could be said of the 1805 Constitution, which fills that identitarian opposition with a new racial content by declaring all Haitians to be Black. For Buck-Morss, this is a dangerous inversion and an attack on heterogeneity, both compatible with a continuation of the racial order and "in tension with the idea of universal emancipation" (145). Universal freedom, for Buck-Morss, seems to be more compatible with the qualifier "French" than the qualifier "Black." But in contrast to this flat reading of the 1805 Constitution, Sibylle Fischer has demonstrated the "complicated and dialectical" interplay between the universal and the particular that characterizes this document:

[E]quality and difference, universalism and identity-based or historical claims, show themselves as intimately linked and indeed inseparable. Universalism and particularism continuously refer back to each other-racial equality cannot be achieved without particularistic claims, and particularism is ultimately justified by a claim of universal racial equality. ${ }^{21}$

Whereas Article 12 bans whites from the status of master and from property ownership, Article 13 quickly exempts naturalized white women and their children, as well as the Poles and Germans who had joined the revolutionary cause, and this loosening of racial categories is then followed by the wrecking-blow of Article 14, which famously declares that "Haitians will henceforth be known by the generic denomination of blacks."

Just as whiteness became a political category in the struggle against the French, so too with blackness in the 1805 Constitution, a porous and expansive category that includes all those who cast their lot in with the new nation. ${ }^{22}$ But Buck-Morss neglects this expansiveness by suggesting that "all other whites" were subject to Article 12, whereas according to Article 14 all naturalized Haitians would fall into the same category through the elimination of whiteness entirely as a category of standing (75n141). More troubling still is her banishing of this moment of exceptional porosity to a footnote, as though awaiting another effort to read the margins. However, whereas Fischer sees the legislation of Black identity as a "troubling paradox" of universalism - the generalization of yet another particular that 
as a result "erases difference" - I want to push further to insist that not all particulars are functional equivalents, and not all generalizations thereof are examples of a shared "paradox" of universalism (233-234). This was not just any particular, and to generalize blackness - the bedrock category upon which white supremacy rests-is a far cry from the generalization of whiteness that has predominated throughout history. This was not a mere inversion, but instead an ultimately failed attempt to topple the structure of racial privilege once and for all.

For Buck-Morss, the rise of Dessalines, the slaughter of the whites, and the legislative uniformity of Haitian blackness all point in one direction: that of a simple inversion in which the last become the first but little else changes, yet another turn in the "recurring cycle of victim and aggressor" (150). In her text, an epigraph from Dessalines appears conspicuously under the heading "Avenging Angels" in which the newly crowned Emperor delights at having responded to the French "war for war, crime for crime, outrage for outrage... I have avenged America" (143). Despite professing that hers is not a "morally pure" drama, Dessalines is unambiguously cast as villain, hell-bent on destroying the universal, and synonymous with all selfprofessed vanguards: from bin Laden to Lenin to George W. Bush $(138,143)$. I have argued, by contrast, that not only is the Manichaeism of the 1804 Declaration political in nature and dynamic in its playing out, but also that the embodiment of this Manichaeism in the 1805 Constitution does not fix racial categories-as Buck-Morss would have it-but instead aspires to upend them.

C.L.R. James has argued that "it was in method, and not in principle, that Toussaint failed" (283), but it should be clear by now that this was indeed a question of principle, and the method he refers to-which Dessalines would grasp properly - is precisely that of relating principles to action. A fixation on universal principles provokes a crisis of action expressed as hesitation, and Toussaint's "hesitations were a sign of the superior cast of his mind. Dessalines and Moïse would not have hesitated" (281). David Scott goes further, suggesting that hesitation was a mark not only of the impact of enlightenment, but of the Enlightenment, enamored as it was of abstract principles. Toussaint epitomized the contradictory ideal of autonomy, "invulnerable to any desire to act against an antecedently held principle," rational to the point of irrationally believing he could "impose his will on the chaos... of the incipient revolutionary movement." ${ }^{23}$ In his "Platonic abstractness," Toussaint embodies the very sort of Hegelianism that Buck-Morss claims to shed:

What Toussaint harbors... is a Hegelian dream that a synthesis or reconciliation is possible, that the old conflicts can be resolve in a higher unity among blacks, whites, and mulattoes...a humanist hope...racial harmony...guided by the abstract principles of liberty, equality, and fraternity. ${ }^{24}$ 
More precisely, what Toussaint harbored was the dream that such a synthesis was immediately available, and that the principle of racial equality could be deployed as a guide for action in the present. James remains ambivalent toward Toussaint, however, but even this ambivalence allows him to surpass Buck-Morss' celebratory universalism. In shifting our focus from the massacred whites to the Black masses and allowing the strategic moment of the here-and-now to play out via Dessalines' "method," James' ambivalence remains dialectical whereas Buck-Morss instead blocks that path forward by disavowing Black identity. The parameters of this error appears clearly once we break one final silence in Buck-Morss' account, turning to an author who has grappled with questions of decolonization, race, identity, and Manichean oppositions through a more thoroughly radicalized variant of Hegel's master-slave dialectic: Frantz Fanon.

\section{Listening to Fanon}

The exclusion of Dessalines from the project of universal history coincides with another exclusion: that of Fanon and his powerful critique of Hegel's master-slave dialectic. Since Buck-Morss' subject is this same dialectic and her analysis of it is situated within the ambit of race, slavery, and colonization, one would expect more of an engagement with Fanon's radical reformulation. ${ }^{25}$ Moreover, in grappling with the dilemmas of insurgency and the tension between Manichean oppositions and universal futures, neglecting an insurgent-theorist whose work sought to dialectically overcome Manichaeism would seem a serious oversight. And yet on the surface, the two thinkers could not seem more opposed: where Buck-Morss sees in the slaughter of the whites a retreat from the universal, "the rotting cadaver of the colonist" constitutes for Fanon the "only work" - in Hegelian terms - by the colonized that could possibly lead to that universal. ${ }^{26}$ Like Fanon, Buck-Morss sets out from a reading of the master-slave dialectic that echoes Alexandre Kojève in its inverted structure: whereas Hegel begins with the "trial by death" (Phenomenology §§187-188) only to trail off as the slave achieves "existing-being-for-itself" through labor (§§195-196), in BuckMorss and Fanon this order is reversed to foreshadow future struggles. ${ }^{27}$ Rather, the fundamental difference lies in Fanon's crucial second step, whereby this Kojèvean dialectic is completely infused with the requirements of Black (and later colonial) existence.

For the Fanon of Black Skin, White Masks, "ontology is rendered impossible" under colonization by the presence of "an impurity or a flaw that prohibits any ontological explanation." 28 What this means is that the two abstract individuals that confront one another in Hegel's Phenomenology are not abstract at all, but instead carry with them the weight of a colonial-racial history of which this "flaw" is a painful reminder: one is fully human, the other is not. Lacking "ontological resistance," the colonized is condemned to 
a "zone of nonbeing," and does not appear on the plane of reciprocity that is the precondition of Hegel's master-slave dialectic (90, xii). ${ }^{29}$

For Hegel there is reciprocity; here the master scorns the consciousness of the slave. What he wants from the slave is not recognition but work... The black slave wants to be like his master. Therefore he is less independent than the Hegelian slave. For Hegel, the slave turns away from the master and turns toward the object. Here the slave turns toward the master and abandons the object (195n10).

The master-slave relation lacks the very basis for recognition that is presupposed in the Hegelian formulation, and as a result, this ontological "flaw" makes subjective, autonomous action by the racialized-colonized necessary before the dialectic can overcome Manichaean frozenness and begin to move. The identitarian moment thereby becomes an essential step toward the universal. While observing the role of "thinghood" in Hegel's dialectic, Buck-Morss does not fully probe the implications of this insight, and instead leaves Hegel's dialectic intact, reading into his pregnant silence the historical reality of the Haitian Revolution: where the master-slave dialectic suddenly falls silent, "the slaves of Saint-Domingue were, as Hegel knew, taking that step for him," writing the conclusion he did not (54, 55n96). Fanon, by contrast, fundamentally transforms the dialectic from the bottom-up, not by providing the missing conclusion, but by critically interrogating its point of departure.

The implications are profound both within Fanon's work and for explaining the very different conclusions of a nominally anti-colonial and dialectical thinker like Buck-Morss, and these are broadly twofold. Firstly, by leaving Hegel's dialectic intact, Buck-Morss leaves intact as well Hegel's yardstick for progress: freedom, understood largely formally. Hence her privileging of emancipation over independence and her celebration of Toussaint's 1801 Constitution, which she emphasizes not primarily for its impact but for its formally universal content. The entire point of Fanon's reformulation of Hegel's dialectic in his post-emancipation moment rests upon a critique of such formalism, according to which slavery was largely abolished from above and "the black man was acted upon" (Black Skin, 194). This sentiment finds preemptive echo in the 1804 Declaration of Independence, as well as in the fact that, given the motivations of the French, emancipation and independence were irretrievably linked. In such a context, prevailing notions of formal freedom and universal equality are worse than empty words, but even constitute an active barrier to the universal by foreclosing - as Buck-Morss does - on struggles that might be deemed too particular.

Secondly, and more importantly, however, is the question of how this dialectical motion connects to the universal that Buck-Morss seeks to 
redeem. If symmetry is presumed as our starting point, then it makes sense to look toward a world of reconciled universal humanity, as with Toussaint's 1801 Constitution and Buck-Morss' embrace of it. But if we see struggle as the necessary precondition for this recognition (Hegel), and if more importantly we see one-sided, pre-dialectical struggle as the necessary precondition to even this Hegelian struggle for recognition (Fanon), then our understanding of the temporal structure of the dialectic shifts accordingly. For Fanon, the ontological blockage of white supremacy creates a more immediate perspective that foregrounds identitarian struggle in the present. Despite his own yearning for the universal-best expressed in the introduction and conclusion of Black Skin, White Masks - Fanon finds identity repeatedly forced upon him, and his universal is deferred into the distant future.

When Fanon later transposes this radicalized Hegelian dialectic onto the colonial situation, the question of Manichean oppositions is posed even more clearly. Famously describing the colonial world as a "Manichaean world... divided in two," he is openly provocative in his insistence that decolonization begins with the very sort of dialectical reversal that BuckMorss abhors, in which "the last shall be first" (Wretched, 2-6). Much like the avenging angel Dessalines, the colonized returns upon the colonizer the "same violence... which governed the ordering of the colonial world," and as though rejecting reconciliation outright, Fanon insists that decolonization "does not mean that once the borders have been eliminated there will be a right of way between the two sectors. To destroy the colonial world means nothing less than demolishing the colonist's sector" (5-6). As though responding preemptively to Buck-Morss' approach, Fanon insists that decolonization "is not a discourse on the universal," with emphasis on both "discourse" and "universal": there is no convincing the colonizer in words, much less in the flowery words of human love that even Fanon himself often uses.

And yet few, Buck-Morss included, seem to read beyond this first chapter and its description of the first stage of decolonization, in which the colonial world is unified by "a radical decision to remove its heterogeneity, by unifying it on the grounds of nation and sometimes race" (10). Nothing would seem more anti-universal than this, but once decolonization begins and Manichaean oppositions groan reluctantly into dialectical motion, categories begin to loosen:

The people then realize that national independence brings to light multiple realities...clarification is crucial as it leads the people to replace an overall undifferentiated nationalism with a social and economic consciousness. The people who in the early days of the struggle had adopted the primitive Manichaeanism of the colonizer-Black versus White, Arab versus Infidel-realize en route that some blacks can be whiter than the whites (93). 
The inverse is also true, and in a striking parallel to the 1805 Haitian Constitution, in which those "whites" who struggled alongside the nation were baptized into blackness, Fanon writes that "some members of the colonialist population prove to be closer, infinitely closer, to the nationalist struggle than certain native sons. The racial and racist dimension is transcended on both sides" (95). The nation itself, seemingly founded on anti-universal identitarianism, is revealed to be a dialectical project-inmotion.

Against Buck-Morss' celebration of 1801, Fanon's critique therefore leans - in words, at least-toward Dessalines' 1804 Declaration and 1805 Constitution, but more importantly it insists that what matters more than words are the historical events and mass struggles they index. After all, as James put it: "phases of a revolution are not decided in parliaments, they are only registered there" (81). Fanon's reformulated dialectic thereby entails immediate skepticism toward the formalism with which Toussaint embraced the Rights of Man and a suspicion that, beneath the formal equality of emancipation, white supremacy continued to operate in a manner that threatened even formal freedom. Most importantly, however, Fanon's identification of the "zone of nonbeing" confirms our reading of the 1805 Constitution: rather than enforced uniformity as in Buck-Morss' (mis)reading, the declaration that all Haitians would henceforth be Black constituted a promotion to Being of those who had previously been condemned (damnés) to nonbeing. A reversal, yes, but a profoundly generative one that was far more dialectical than Manichaean.

\section{Conclusion: Insurgent Dilemmas?}

What is erased with Dessalines returns in Buck-Morss' account as the "dilemma of the insurgent": action is necessary but threatens humanity, since the enemies of humanity appear as targets of brutality. "What dialectical understanding," she asks, "will provide liberation from this contradiction?" (134). To reclaim the universal while shedding the more conservative elements of the Hegelian legacy means, for Buck-Morss, to celebrate moments of rupture and anomaly and to reject the absoluteness of inherited categories and identities, emphasizing instead their "porosity" (111). But she quickly shifts from the porosity of identities to their outright rejection in her insistence that "liberation from the exclusionary loyalties of collective identities is precisely what makes progress possible in history," adding that such liberation occurs "not across national boundaries but without them" (149-151). Railing against "racialist nationalism" and "national and partial" identities, and celebrating those truly "cosmopolitan" movements who "spoke of one race, the human race," this self-professed dialectician suggests that historical progress proceeds not through rupture and identitarian conflict, but rather through the immediate and 
unconditional assertion of universality as fact (106-107). We would therefore be justified in wondering what on earth remains dialectical in Buck-Morss' universal history.

When nations coalesce, subnational collectives emerge in opposition to them; when class identities weigh too heavily or uniformly, "anomalies" emerge in the name of gender and race, driven not by the inherent progress of History but by the irrepressible irreverence of subjective struggles: contra Buck-Morss, it would be difficult to think of a single instance of historical progress that is not the result of "collective identities" coming together in struggle, which are frequently dismissed as "exclusionary" and "partial" by those with a vested interest in existing privileges. Further, even many of those laudable "anomalies" that Buck-Morss would center are also political identities, but those nearer their moment of genesis, still fresh and lively with the memory of their raison d'être. At what moment does porosity yield a new collective identity, and when does an anomaly gain the force of history? There would seem to be no qualitative difference between which ruptural identities we privilege as sufficiently porous or anomalous and those we relegate to the dustbin of the past. Further, to view categories dialectically means to grasp their content rather than their formal characteristics, as when James and Fanon allow the concepts of race and nation to shift and acquire new content. If our interest is porosity - as Buck-Morss insists it is - then the emergence of new identities and the infusion of others with new political content should stand front-and-center.

How to explain the shift between Buck-Morss' qualified wariness toward "unthinking" identities that can "mislead political judgment" and her subsequent rejection of such identities in toto? (111). The answer lay, I believe, in a heavy-handed "conceptual ordering" which leads her - like the Hegel she critiques - to approach the universal by negating, rather than truly passing through and inhabiting, the particular. We have seen elements of this ordering in her Eurocentric criteria for the universal, her decision as to which period of the Haitian Revolution was properly universal, her celebration of Toussaint and erasure of Dessalines, and in her privileging of the massacre of the whites over that of the Vodou priests. Was Dessalines blind to porosity when he baptized some Poles and Germans as "black"? Was Fanon blind to porosity when he suggested that "some blacks can be whiter than the whites"? And was not old Toussaint performing the same maneuver when he mobilized on the basis of the nation, and even more so when he reputedly told his troops "leave nothing white behind you" (Black Jacobins, 288)? Despite Buck-Morss' rejection of overarching frameworks of conceptual ordering, she clearly falls into the same.

But most worrying is the way that this ordering is carried out and the blanket rejection of identities that it entails. While insisting that, against Hegel's overbearing universal, "there is no anticipation of unity" in her own approach, Buck-Morss exhorts readers to think in terms "as inclusive as 
humanity itself" (111). Access to the universal thus appears as though unfettered by historical structures of inequality: we can simply will it into being in our rejection of divisive particularities. ${ }^{30}$ But if historical residue is what taints identity, Buck-Morss strangely neglects that any such residue might have settled upon the idea of rejecting all exclusionary identities. Not only does this exclusion of the exclusionary run the risk of the false universalism of which Fanon warned, but it is also powerfully bound-up with the universal pretensions of European thought itself. What creative possibilities for humanity are excluded in the name of rejecting exclusionary identities, and what use is a commitment to the porosity of identities if these are already overdetermined as repressive barriers to the universal?

Buck-Morss speaks of the "paradox" whereby collective identities aspiring to the universal nevertheless establish their identity in opposition to others (110). What she neglects is that, rather than a paradox, such opposition-aside from being built-into the lives of many who enter into struggle-does not imply the permanent closure of that identity. One does not merely risk one's life, one risks one's life against, and yet the lure of the universal is such that Buck-Morss rejects such enmity entirely, thereby robbing those struggling of the tools necessary to move forward. This thinker who critiques Hegel for having fallen silent at the moment of dialectical consummation herself falls silent and silences others in the same gesture, and this silence is far from coincidental: Buck-Morss' project of universal history explicitly shuns the identitarian, conflictive moment that stands at the heart of a radicalized dialectics

Rather than shedding the worst elements of the Hegelian legacy rather than abandoning its "anticipation of unity" - Buck-Morss in fact succumbs to the lure of anticipation in her immediate embrace of the universal. Fanon's words, once launched against Sartre, here apply quite well:

We had appealed to a friend of the colored peoples, and this friend had found nothing better to do than demonstrate the relativity of their action. For once this friend, this born Hegelian, had forgotten that consciousness needs to lose itself in the night of the absolute, the only condition for attaining self-consciousness (Black Skin, 112, translation modified).

Much as Sartre subsumed Black identity as a "minor term" in a broader dialectic whose outcome was the universality of class, so too does BuckMorss similarly subsume "partial" black and national identities, and the resistance they engender, to her broader universal. Were this truly a new humanism, however, this subsumption would not be necessary and nor would it be predefined according to European criteria: the significance of the Haitian Revolution would not be to prove the universality of the French Revolution, but rather - in the words of Fanon's conclusion to Wretched of the 
Earth - to "flee this stagnation where dialectics has gradually turned into a logic of the status quo" (237). But unlike Sartre, Buck-Morss does more than merely subsume the ostensibly particular, she openly rejects it, and as a result, her betrayal is arguably more galling than was Sartre's: whereas Sartre had at least recognized the dialectical importance of black identity, Buck-Morss dissolves all such identities immediately and unconditionally into her "new humanism."

Fanon also sought to craft a new humanism, an aspiration he inherited from his great teacher Aimé Césaire, but unlike Buck-Morss, their humanism is truly decolonial and dialectical. A decolonized dialectics is powerfully attentive to the realm of non-being, and consequently to the need for pre-dialectical struggle by the colonized and racialized to set history into motion, creating new humans in the process. Such a dialectics cannot therefore reject the categories of collective action a priori, as though willing away the entire structure of colonialism and racial overdetermination. Instead these must be grasped firmly and filled with the aspirations of those who take them up as a mantle and a banner. While Buck-Morss notes Césaire's excitement at Hegel's suggestion that "to arrive at the Universal, one must immerse oneself in the Particular" (16), she fails to accompany that process of immersion, and as a result cannot grasp what Césaire himself would later deem a "universal rich with all that is particular." 31

What would Buck-Morss tell a contemporary Dessalines? Must they simply accept the fate of a Toussaint, sacrificing themselves on the altar of the universal?

1 On Hegel, see Fredric Jameson, Valences of the Dialectic (London: Verso, 2009); as well as Slavoj Žižek's gargantuan Less Than Nothing (London: Verso, 2012). On the renewal of communism, see especially Alain Badiou, The Communist Hypothesis (London: Verso, 2010), Bruno Bosteels, The Actuality of Communism (London: Verso, 2011), and Jodi Dean, The Communist Horizon (London: Verso, 2012); and on contemporary forms of struggle, Badiou's more recent The Rebirth of History (London: Verso: 2012).

2 Sibylle Fischer, Modernity Disavowed: Haiti and the Cultures of Slavery in the Age of Revolution (Durham: Duke University Press, 2004).

3 Antonio Vázquez-Arroyo, "Universal History Disavowed: On Critical Theory and Postcolonialism," Postcolonial Studies 11, n. 4 (2008), 452.

4 While I move here between the terms postcolonial-which Vázquez-Arroyo uses-and decolonial, there is a crucial difference between the two, in practice at least. On the most literal level, decolonial theory-which emerges above all from Latin America-tends to reject the idea that ours is a "post"-colonial world, opting instead for the continued impact of what is called coloniality. In part owing to this, decolonial thought is often critical of what is perceived to be a residual Eurocentrism in many approaches to postcoloniality. 
${ }^{5}$ Alain Badiou, Ethics: An Essay on the Understanding of Evil (London: Verso, 2001); Slavoj Žižek, "A Leftist Plea for 'Eurocentrism'," Critical Inquiry 24, n. 4 (Summer 1998), 988-1009. For a critique of the latter, see Nelson Maldonado-Torres, "Decolonization and the New Identitarian Logics After September 11," Radical Philosophy Review 8, n. 1 (2005), 35-67.

${ }^{6}$ Susan Buck-Morss, "Hegel and Haiti," Critical Inquiry 26 (Summer 2000), 821-865; Susan BuckMorss, Hegel, Haiti, and Universal History (Pittsburgh: University of Pittsburgh Press, 2009), hereafter cited in the text. As should be clear, this article does not-and cannot hope to-do justice to the newly expansive literature on the Haitian Revolution. Instead, I hope to draw upon both the contours of the revolutionary process, but more importantly the meaning and interpretations of those contours, in an attempt to rethink the relationship between identity, dialectics, and the universal.

7 See, e.g., Susan Buck-Morss, The Origin of Negative Dialectics: Theodor W. Adorno, Walter Benjamin, and the Frankfurt Institute (New York: The Free Press, 1977); The Dialectics of Seeing: Walter Benjamin and the Arcades Project (Boston: MIT Press, 1991).

${ }^{8}$ Slavoj Žižek, First as Tragedy, Then as Farce (London: Verson, 2009), 111-112.

9 By contrast, C.L.R. James demonstrates that the black revolutionaries actively prefigured and even pushed the French Revolution itself, whether he meant to or not. C.L.R. James, The Black Jacobins (New York: Vintage, 1989), hereafter cited in the text.

10 In a footnote, however, Buck-Morss cites Michel-Rolph Trouillot's claim-which plainly contradicts her own-that the Haitian and not the French Revolution constituted "the most radical political revolution of that age." Michel-Rolph Trouillot, Silencing the Past (Boston: Beacon, 1997), 98.

11 Fischer concludes that the 1801 Constitution posits "Free and French" as "inseparably linked attributes" that contain "all possible futures" (Modernity Disavowed, 229-230).

12 John Relly Beard, The Life of Toussaint L'Ouverture (London: Ingram, Cooke, and Co., 1853), 327328.

13 David Scott, Conscripts of Modernity: The Tragedy of Colonial Enlightenment (Durham: Duke University Press: 2004), 20.

${ }^{14}$ C.L.R. James, “Lectures on the Black Jacobins," Small Axe 8 (2000), 110.

15 Or as Scott puts it, "the tragedy of enlightenments is that what lies immediately before one is often obscured by the very fact that one can see what lies in the distance-seeing the forest, sometimes, obscures the trees" (207).

16 The reference is to Black Jacobins, 276n6, but the explication is from "Lectures," 105.

17 “Lectures," 105.

${ }^{18}$ Carolyn E. Fick, The Making of Haiti (Knoxville: University of Tennessee Press, 1990), 233. BuckMorss mentions this slaughter on 138, but it plays no prominent role in the argument. Perhaps since it was carried out by Dessalines but under Toussaint's orders, it is too embarrassing to mention.

19 The 1804 Declaration was penned by Louis Boisrond-Tonnerre who had reputedly expressed his disgust at a tamer initial draft and drunkenly proclaimed that "to draw up the Act of Independence, we need the skin of a white man for parchment, his skull for a writing desk, his blood for ink, and a bayonet for a pen." Dessalines heard this outburst, replying affirmatively, "That is right, sir, that is right, that is my wish. I need white blood." Nicholls, From Dessalines 
to Duvalier: Race, Colour, and National Independence in Haiti (New Brunswick: Rutgers University Press, 1996), 36.

20 This critique of formal principles is complemented by a prescient critique of the drawbacks of any merely formal liberation after which "everything still carries the stamp of the French." Text from Laurent Dubois and John D. Garrigus, Slave Revolution in the Caribbean, 1789-1804 (Boston: Bedford/St. Martin's, 2006).

${ }^{21}$ Fischer, Modernity Disavowed, 231-232.

22 Fischer explains the shift from an ostensibly 'anti-white' article to one which loosens the category of white, and finally to one which deems all Haitians unambiguously black by arguing that the concept of race for those drafting the document shifted during the course of debating, and promulgating the Constitution (234) (although my reading of the 1804 Declaration would suggest that race had already been circulating as a political category). Fischer further argues that even understood on its own, Article 12 must be interpreted-in the context of continued slavery-as more political than racial (235).

${ }^{23}$ Scott, Conscripts, 200-201.

24 Scott, Conscripts, 202-205.

${ }^{25}$ Fanon is mentioned a single time, in a footnote, and even this mention manages to distort his thought: for Buck-Morss, Fanon's goal is "attaining equal recognition in terms of their own cultural values" (56fn102).

${ }^{26}$ Frantz Fanon, The Wretched of the Earth, tr. R. Philcox (New York: Grove Press, 2004), 50.

27 Buck-Morss, Hegel, Haiti, and Universal History, 53-56. See Alexandre Kojève, Introduction to the Reading of Hegel, trs. James H. Nichols, Jr. (Ithaca: Cornell University Press, 1969). On Kojève's dialectic and Haiti, see Fischer, Modernity Disavowed, 29-33.

${ }^{28}$ Frantz Fanon, Black Skin, White Masks, trans. Richard Philcox (New York: Grove Press, 2008), 8990, translation modified, my emphasis. Hereafter cited in the text.

29 For further elaboration of this "circularity" in Hegel, see George Ciccariello-Maher, "The Dialectics of Standing One's Ground,” Theory \& Event 15 n. 3 (2012).

30 Stephanson is therefore correct in his critique of Buck-Morss's approach as "in every way idealist" and "devoid of strategic content, since none can appear within her undifferentiated 'humanity'." Anders Stephanson, “The Philosopher's Island," New Left Review 61 (JanuaryFebruary 2010), 194.

31 Cited in Robin D.G. Kelley, “A Poetics of Anticolonialism," in Aimé Césaire, Discourse on Colonialism, 25-26. 